NBER WORKING PAPER SERIES

\author{
CYCLICAL VERSUS SECULAR \\ MOVEMENTS IN EMPLOYMENT \\ CREATION AND DESTRUCTION
}

Randall W. Eberts

Edward Montgomery

Working Paper No. 5162

\author{
NATIONAL BUREAU OF ECONOMIC RESEARCH \\ 1050 Massachusetts Avenue \\ Cambridge, MA 02138 \\ June 1995
}

The authors wish to thank Bennett Harrison, Jagadeesh Gokhale, and seminar participants at Northwestern University and the Federal Reserve Banks of Chicago and New York for helpful comments on an earlier draft of this paper. Steve Davis and John Haltiwanger were generous with their data and expertise on this topic. All errors and opinions are the authors'. This paper is part of NBER's research program in Labor Studies. Any opinions expressed are those of the authors and not those of the National Bureau of Economic Research.

(C) 1995 by Randall W. Eberts and Edward Montgomery. All rights reserved. Short sections of text, not to exceed two paragraphs, may be quoted without explicit permission provided that full credit, including $\odot$ notice, is given to the source. 


\title{
CYCLICAL VERSUS SECULAR \\ MOVEMENTS IN EMPLOYMENT \\ CREATION AND DESTRUCTION
}

\begin{abstract}
This paper offers an analysis of cyclical and secular patterns in job turnover using establishment-level data. We provide evidence from multiple data sets that show that the job turnover process is markedly different over time and across regions. Over time, we find that employment fluctuations are associated primarily with job destruction. Across regions, employment differences are associated more with job creation. Differences were found between the cyclical (within) and secular (across state) responses in job creation and destruction to output shocks. Movements in job creation and destruction were also found to be related to the types of human capital externalities or technological spillovers used to explain long-run differences in regional or national growth rates.
\end{abstract}

Randall W. Eberts

W.E. Upjohn Institute

for Employment Research

300 South Westnedge Avenue

Kalamazoo, MI 49007
Edward Montgomery

Department of Economics

University of Maryland

College Park, MD 20742

and NBER 


\section{Introduction}

Most assessments of labor market performance over a business cycle or across regions focus on net employment change. Hidden behind the veil of these aggregate numbers are four components of employment change: jobs gained from business openings, jobs gained from business expansions, jobs lost from business contractions, and jobs lost from business closings. Recently, several studies have identified and examined these components temporally (e.g., Davis and Haltiwanger, 1990) and cross sectionally (e.g., Dunne, Roberts, and Samuelson, 1989) to attain additional insights into the performance and dynamics of labor markets.

Labor market dynamics are characterized by two types of turnovers. One is the transition of workers into and out of positions; the second is the change in the number of jobs. While these turnover dynamics are interrelated, they can be characterized as supply and demand responses. Workers move between jobs to better match their skills, wage expectations, and work place preferences with the attributes of the position. Businesses change the number and type of employment positions in response to changing product demand and factor costs. Traditionally, research on labor market dynamics has concentrated on supply-side responses to labor market shocks by examining worker decisions to move into and out of the labor force or between employment and unemployment.

This paper focuses on jobs by tracking employment changes resulting from the opening, expansion, contraction, and closing of individual establishments. In particular, we look at whether the components of cyclical and secular (regional) variations in employment growth follow similar patterns. Are fluctuations in employment over business cycles 
correlated more with variations in job creation (openings and expansions) than with variations in job destruction (contractions and closings)? Is employment growth in some regions characterized by greater job creation or fewer job losses? What factors determine the cyclical and secular patterns of job creation and destruction?

Although there has been substantial work on high frequency movements in job creation and destruction because of their importance for business cycles, we are not aware of any studies that have explicitly compared the cyclical and regional behavior of these employment components. Our evidence suggests that these components of net employment growth behave quite differently over time and across regions. We find that employment fluctuations over business cycles are associated primarily with job destruction, whereas employment growth rate differences across regions are associated more with job creation.

These insights may have relevant policy implications at both the local and national levels. For instance, since regional employment differences are correlated more with job creation than with job destruction, state and local policies aimed at promoting new firm creation and expansion might be more fruitful in the long run than those aimed at aiding ailing firms. On the other hand, since cyclical employment is associated more with job destruction, it may be prudent to design policies to help firms through economic downturns so that fewer workers are laid off and less hardship is incurred. Clearly, definitive policy recommendations must await a more structural analysis of the determinants of job creation and destruction. Nonetheless, these results may be of value in guiding this structural modeling and may serve as a cautionary note to policy makers that some existing actions may be swimming upstream against the economic forces that generate employment growth. 


\section{Definitions and Data}

The four components of net employment change are measured with respect to a specified time interval. An establishment is considered an opening if it did not exist at the beginning of the interval but did exist at the end. A closing is defined conversely. Therefore, employment gains from openings are the summation of employment in establishments that were not present at the beginning of each period but that did exist at the end of the period. Employment losses from closings refer to employment at those establishments that existed at the beginning of the period, but absent at the end of the period. Employment changes due to expanding or contracting firms are based on employment changes at those entities in existence at both the beginning and end of each period.

Two issues of measurement arise that affect the relative contributions of these four components of net employment change. The first is the frequency of observations. The proportion of jobs created from openings or expansions (or lost as a result of closings or contractions) is sensitive to the length of time between the beginning and the end of the period used to construct the four components. Given a time-invariant stochastic process of openings and closings, a greater proportion of employment gains would be attributed to openings than expansions as the period between observations lengthens. Obviously, it is also true that the longer the observation period the less likely short lived jobs will be observed at all, and hence the greater the tendency to underestimate each of these flow components.

The second issue is the construction of the opening and closing components. A "new establishment" is typically defined as a newly created institution, typically located in one place, that combines labor, capital, and purchased inputs to produce goods or services. 
However, the exact treatment of mergers and acquisitions, changes in management or ownership, and the movement of establishments from one location to another can be problematic.

Clearly, measuring the four employment components requires extensive data collection. Studies of the demand-side components of employment change depend upon longitudinal establishment-level data. At present, four U.S. data sets are appropriate for examining job dynamics: the Unemployment Insurance/ES202 data, the Longitudinal Research Datafile (LRD), two extracts of the Dun \& Bradstreet credit records, and the new Census-based Small Business Data Base. All four are derived from information collected for purposes other than constructing a longitudinal file of employment, so each has its strengths and weaknesses. In this paper we use primarily the LRD and Dun \& Bradstreet data extracts because they are the only ones that would allow us to look across a broad range of geographic areas. Because these data sets are derived from different sources, cover differ industries, and differ in geographical scope, it is useful to discuss the construction of these data sets and to compare their estimates of the importance of these components of employment.

\section{Censuses and Surveys of Manufacturers}

The Census Bureau collects detailed information on manufacturing establishments on an annual basis through the Annual Surveys of Manufacturing and on a decennial basis through the Census of Manufacturers. The latter includes a complete accounting of all manufacturing establishments during the years $1967,1972,1977,1982$, and 1987 . The annual surveys provide a probability-based sample of roughly 25 percent of the 
establishments.

Two different longitudinal manufacturing data sets have been constructed from the Census of Manufacturing files. The first, used by Dunne, Roberts, and Samuelson (1989), link the Censuses to form a panel that observes manufacturing establishments every five years. The second, constructed by the Census Bureau and called the Longitudinal Research Datafile (LRD), links both the annual surveys and the decennial Censuses to form a panel with annual and quarterly observations. These data have been used by researchers, most notably Davis and Haltiwanger (1990), to estimate high-frequency employment dynamics. The primary advantage of the LRD is that it combines high-frequency observations with a long-enough time series to look at cyclical changes. The five-year panel used by Dunne, Roberts, and Samuelson, on the other hand, takes advantage of a complete census of manufacturing establishments, but misses elements of transitory or short-run employment dynamics, since establishments are created and destroyed within these five-year intervals. The longitudinal matching of manufacturing establishments is based on plant identification, which does not change if a firm merger or acquisition simply reflects a transfer of ownership. Although matching problems still arise (see Dunne and Roberts [1986] for details), the data set measures actual firm exits and entries as accurately as any other source. The major drawback of the Census-based manufacturing files is coverage. Since these data include only manufacturing industries, however, they are not suitable for studying employment dynamics in other sectors and may not represent the economy as a whole. 


\section{Census-based Small Business Data Base}

Beginning in 1991, the Small Business Administration (SBA) contracted with the Economic Surveys Division (ESD) of the Bureau of the Census to produce linked longitudinal files on an enterprise basis. These files were based upon a match between the two major Census files. The first is the Census's main mailing list, the Standard Statistical Establishment List (SSEL), and the second is the annually updated Company Organization Survey (COS), in which firms with 50 or more employees list all of the component establishments which they own as of March in each year. The establishment is the main building block of this data base, and establishments are classified by the size of firms that own them. One advantage of this data base is that all industries are completely covered (the coverage matches that in the Census's annual County Business Patterns). Another advantage is that the data are divided into sub-national geographical regions (e.g., states and census regions).

\section{Dun \& Bradstreet Data}

The Dun \& Bradstreet Company maintains information on nearly 5 million businesses in every major industry and region of the country to assess their credit worthiness. The advantage of the Dun \& Bradstreet data is their broad coverage of industries and regions. Birch (1981) was the first to use Dun \& Bradstreet data to construct longitudinal files of establishments. During the early 1980s, the Small Business Administration contracted with Catherine Armington and Marjorie Odle of the Brookings Institution to construct a longitudinal establishment database from the Dun \& Bradstreet files.

Data sets derived from Dun \& Bradstreet files have several problems that are not 
present in files derived from Census data. One problem stems from the fact that the Dun \& Bradstreet data set is neither a census, as is the Census of Manufacturers, nor a scientifically sampled survey, such as the Survey of Manufacturers. Dun \& Bradstreet collects information on individual firms and establishments to assess their credit ratings. Therefore, biases may exist in the identification of establishments, the number and type of establishments sampled, the frequency of sampling, and the updating of records.

In particular, Dun \& Bradstreet changes an establishment's identification if a company is merged or acquired. This practice may lead to an over counting of the number of openings and closings, since a change in ownership is counted as both an opening and a closing. However, Howland (1988) found that this feature of the Dun \& Bradstreet procedure did not induce a serious bias.

On the other hand, Dun \& Bradstreet is sometimes slow to include new firms and tends to miss some openings completely, as it fails to count new branches of multi-establishment firms unless they have separate credit reports. Thus, the failure to update records on a timely basis may underestimate the jobs lost due to closings and gained due to openings. ${ }^{1.2}$ Jacobson (1985) compares Dun \& Bradstreet data with ES202/UI data

1 Researchers have adjusted for this under counting by following a two-step imputation method. First, they estimate the rate at which Dun \& Bradstreet records openings between 1969 and 1980 for each of several industries. Then they multiply the actual openings contained in the files by the appropriate absorption rates to approximate the incidence at which startups actually occur. However, Howland (1988) and Jacobson (1985) have pointed out several problems with this method. First, it assumes a constant absorption rate, which does not take into account the improvement in Dun \& Bradstreet's recording of openings during the 12-year period. Second, it makes the unrealistic assumption that employment creation at nonsampled firms is the same as at sampled firms. Because of the company's incentive to include all active and large firms, it is more likely that unrecorded openings have fewer employees than recorded ones. 
for Texas. He finds two somewhat offsetting biases. Reporting lags and failure to characterize openings and continued operations properly led the Dun \& Bradstreet data to overestimate employment and employment growth from openings over closings in small, independent firms. At the same time, employment in large, multi-unit firms is underestimated. With these offsetting biases, Jacobson concludes that measurement of overall employment growth with Dun \& Bradstreet data is reasonably accurate, but that openings may be overestimated compared with closings.

In sum, each data set has advantages and disadvantages in constructing the four employment components and in analyzing the job turnover process over time and across regions. There is a general consensus that the census-based data sets are the least problematic. However, there are tradeoffs in using them. Davis and Haltiwanger's data set covers only manufacturing, which is only 17 percent of the U.S. work force, but the data set provides the longest time series. The SBA data sets, both from Census and Dun \& Bradstreet, cover all industries and geographical areas but includes only a few years. Thus, to provide broader coverage and to be able to generalize beyond manufacturing, it is instructive to compare the employment components derived from the various data sets.

\section{Summary of Previous Studies}

Table 1 summarizes the employment components reported by various studies that use the data sets previously described. Comparisons among the studies are somewhat difficult

${ }^{2}$ The closing bias has been addressed in two different ways. One is to assume that the establishments purged by Dun \& Bradstreet are still operating and to include them in the data set. Alternatively, one can follow Dun \& Bradstreet's procedure and treat the purged establishments as actual closings. 
because not only do the data sets differ in construction, but analysts have chosen to study different years and to use intervals of different lengths in constructing the components. Even so, several similarities stand out.

First, gross employment flows are larger than net employment changes. Thus, net employment changes substantially understate the amount of turnover or job creation and destruction taking place in the market. Dunne, Roberts, and Samuelson (1989) also find considerable heterogeneity in conditions at establishments within regions and industries. For instance, between 1977 and 1982, for every position gained in an expanding industry, 0.604 jobs were lost. For every position lost in a contracting industry, 0.644 were added. Similar patterns were also found across growing and declining regions. For every job lost in a contracting region, 0.724 jobs were added, while for every job gained in an expanding region, 0.728 were lost.

Second, as shown in the last two columns of table 1 , there appears to be considerable variation across studies in the contribution of openings to job creation and closings to job destruction. Employment from openings as a proportion of total job creation ranges from 18 percent to nearly 71 percent. Employment loss from firm closings as a proportion of total job destruction exhibits a similarly wide range of values. For instance, Dunne et al. (1989) and Davis and Haltiwanger (1990) use virtually the same data, but find significant differences in the contribution of openings to job creation and closings to job destruction. Dunne et al. report that 60 percent of job creation is attributable to openings, while Davis and Haltiwanger find that only 20 percent of new jobs comes from openings.

Upon closer inspection, it appears that the primary reason for these differences in the 
proportion of openings to job creations and closings to job destruction is the length of the interval used to construct the components. For example, Dunne et al. uses a five-year interval and consequently attribute all employment growth during the five-year interval to new firms, while Davis and Haltiwanger attribute only the first year's growth to openings. with the rest attributed to expansions. The converse applies to closings relative to contractions. This results in a much larger proportion of jobs created from openings or lost due to closings than reported by Davis and Haltiwanger.

The ratio of openings to job creation and closings to job destruction found by Davis and Haltiwanger for the one-year interval are very similar to the proportions found using the Census-based SBA data. It is interesting that the proportions for the manufacturing sector match the proportions for all industries. The similarities between manufacturing and total employment holds for the D\&B-based data, as well. Based on the work of Armington and Odle, employment components for manufacturing closely follow employment components for all industries. The ratios of openings to job creation and closings to job destruction are quite similar, and each of the four components are reasonably close, particularly after considering manufacturing's relatively slower net employment growth, and at times, employment decline.

It is also worth noting that over longer time intervals that the Dun \& Bradstreet and Census Bureau data yield similar results with respect to the ratio of openings to job creation. Using the Dun \& Bradstreet data and looking only at manufacturing, Armington and Odle (1982) report that openings account for 56 percent of job creation compared to the 60 percent found by Dunne et al. using Census data. This slightly smaller fraction of jobs from openings using the Dun \& Bradstreet data, even though the period was one year longer than 
the Census-based analysis, suggests that this data set's tendency to overestimate openings may not be that serious. The two studies show a larger difference in the fraction of jobs lost from closings, but are still closer than studies using the same data sets but different observation frequencies.

Therefore. after accounting for differences in the interval used to construct the employment components, it appears that the findings from the various studies yield comparable qualitative results.

\section{Accounting for Employment Change Over Time and Across Regions}

To account for employment change over time and across regions, we first examine the variation of each of the four components over time, in order to see which contributes most to fluctuations in employment over business cycles. Similarly, we examine the variation across regions of each of the four components to identify which component is most associated with regional employment growth. Some studies and data sets are more suitable for looking at one perspective than the other, but by considering evidence from the breadth of studies, a composite picture of these two processes emerges.

\section{Variations over Time}

Since Davis and Haltiwanger's study has the most frequent observations of those considered here, and since it spans at least two business cycles (1973-88), it is best suited for looking at the cyclical job turnover process. The authors find that job destruction accounts for most of the net employment change over business cycles. As shown in figure 1 , recessions are marked by a mild decrease in creations but large increases in destructions. Recoveries have lower-than-average destructions and slightly higher-than-average creations. 
The correlation between job destruction and net employment change over the period is higher than the correlation between job creation and net employment change $(-0.96$ vs 0.91$)$.

The results of Dunne et al. (1989) are consistent with Davis and Haltiwanger's findings. However, since data constructed by Dunne et al. are not at business cycle frequencies, only tentative inferences about adjustments over these cycles can be drawn. Comparing periods of employment expansion and contraction, it appears that job destruction accounts for more of the variation in net employment change than does job creation. For example, when the rate of net employment growth fell from a 15 percent increase to a 3 percent decline between 1963-67 and 1967-72, the rate of job destruction increased from 19 percent to 33 percent over this interval, while job gains from creations were only modestly lower, 34 percent versus 30 percent. The same pattern emerges comparing 1972-77 with 1977-82. As the rate of job destruction rose 6 percentage points over this interval, the rate of job creation remained virtually unchanged.

This lack of variation in job creation reflects two offsetting trends. As seen in figure 2, job growth from expanding firms varies procyclically; job growth from openings runs countercyclically. In contrast. both components of job loss are procyclical and appear to be more variable than job creation components.

In contrast to the LRD results, the D\&B data for all industries indicate that job creation is more correlated with net employment change over the business cycle (as represented by the three time periods) than is job destruction. As shown in table 2, the rate of job creation varies by as much as 7 percentage points over the three time periods, while job destruction varies by only 2 percentage points. The Census-based SBA data shows a 
similar pattern as found in the D\&B data. As shown in table 1, between 1989-90 and 199091 , the rate of job creation for all industries falls by about the same amount as the rate of job destruction rises, leaving no clear dominance of one component or the other during this downturn in the economy. Of course, the few time intervals provided by these two data sets offer far from conclusive evidence, but it does raise the question of whether cyclical behavior of the manufacturing sector is representative of the whole economy. Unfortunately, the manufacturing data series is the only one that allows for a rigorous analysis of both the secular and cyclical relationships. we focus primarily on the manufacturing sector for the remainder of the analysis.

$\underline{\text { Variations across Regions }}$

Dunne et al. examine the pattern of gross flows across expanding and contracting Census regions. As shown in figure 3, in two out of three cases, it appears that differences in net employment growth are associated more with differences in job creation rates than with variations in job destruction rates. During the $1967-72$ period, employment gains from openings differed between the two types of regions by about 10 percentage points, while the rate of employment loss due to closings varied by less than 2 percentage points. The same relative differences are found for the $1977-82$ period. ${ }^{3}$

In expanding regions (figure 4), variations in the rate of openings or expansions appear to account for a larger fraction of the overall rate of net employment growth than do

${ }^{3}$ The exception is the 1972-77 interval, in which employment losses resulting from closings vary more than employment gains from openings. However, this period may not be representative of the nature of expanding and declining regions, as only one of the nine Census regions experienced net employment losses during that period. The other two intervals offer a more balanced sample, with declining and expanding regions split evenly. 
variations in the rate of employment loss from closings or contractions. However, for contracting regions (figure 5), changes in the rate at which employment is lost seem to be driven by variations in the rate of employment decline due to closings and contractions. These data suggest two different sources of manufacturing employment change. The primary source of employment variation over time appears to be job destruction components. On the other hand, job creation, particularly from openings, appears to be the primary source of secular rates of employment change across regions. Defining regions as counties, metropolitan areas, states, or Census regions does not alter the basic regional patterns of the four components of net employment change.

\section{New Evidence on Regional Creation and Destruction}

Evidence from these prior studies using the LRD manufacturing data suggests a different pattern of gross employment flows across regions than over time. Over the business cycle (short run), job destruction seems to dominate, while across regions (long run), job creation may be relatively more important. These differences need not be inconsistent any more than finding that, in the short run, aggregate demand disturbances generate most of the variations in output while they play a minor role in explaining long-run growth differences.

The burgeoning endogenous growth literature has focused on the factors explaining long-run growth-rate differences across countries or regions. ${ }^{4}$ They identify human capital externalities and technological spillovers (among other factors) as possible channels for the persistent differences in regional (country) growth rates. Arguably, these factors may be

\footnotetext{
${ }^{4}$ See Romer (1986), Lucas (1988), Krugman (1991), and Glaeser et al. (1992).
} 
unlikely to account for much of the short-run or cyclical variation in growth. Thus, to the extent that they are more highly correlated with job creation than with job destruction, there will be differences in the short- and long-run variability of job creation and destruction rates. In any case, a further examination of the dynamics of employment growth across regions might be useful in casting light on whether models of regional or long-run growth need to focus on factors that differentially affect the job creation process.

Davis and Haltiwanger provided us with their data aggregated by states. We performed an ANOVA analysis to decompose the sum of squares into variation from states and from time (figure 6). The rate of job destruction claims a larger portion of the variation in net employment change than does the rate of job creation. However, what is relevant for our purposes is the relative contribution of time and regional variation for job creation versus job destruction components. We found that state variation explains a larger portion of the model variance for job creation than for job destruction ( 58 percent versus 29 percent). Correspondingly, time variation explained a larger percentage of variation in job destruction than in job creation, which is consistent with Davis and Haltiwanger's findings about dynamics over the business cycle.

This difference in within- and across-state dynamics can also be seen by examining the simple correlations between net employment growth and job creation and destruction rates within (table 3 ) and across states (table 4) using the LRD manufacturing data. Within a state, movements in net employment over time (table 3) are more highly correlated with job 
destruction than job creation $(-.91 \mathrm{vs} .85) .{ }^{5}$ States seem to have fairly homogeneous

responses over time as the distribution of these correlations across states is fairly

concentrated. Over 80 percent of states have a correlation between job destruction and net

employment growth that is greater than the average for job destruction and net employment.

Conversely, almost 70 percent of states have a correlation between job destruction and net

employment growth that is below the mean for job creation and net employment. Thus,

movements in net employment rates within states over time are consistently more closely

related to movements in job destruction than job creation.

Across states (table 4), however, a different pattern emerges. Overall and in 11 of the 16 years for which we have data, state job creation rates are more highly correlated with state net employment growth than is state job destruction. ${ }^{6}$ Interestingly, across states job creation and destruction are on average positively correlated. This pattern also holds fairly consistently in most years that we have data. This contrasts with the pattern over time (within states) where job destruction and creation were strongly negatively correlated. Thus, while job creation may be procyclical and job destruction countercyclical, cross sectionally

${ }^{5}$ These correlations are slightly lower than those reported in Davis and Haltiwanger because we report unweighted average correlation while they report correlations weighted by area size.

${ }^{6}$ By reporting unweighted average correlations we are capturing the responses of the typical state not necessarily of the typical job or the aggregate economy. If one size weighted these correlation (as would be appropriate in a macro analysis) a different pattern emerges. The weighted correlations show that overall and in 11 of the 16 years for which we have data job variation in job destruction rates across states are more correlated with net employment growth variations. The difference in the weighted and unweighted results suggest that in big states net employment growth is driven more by job destruction while in smaller states it is driven by job creation. 
(secularly) dynamic or growing areas have high rates of both creation and destruction.

An alternate way to examine these regional versus cyclical differences in job creation and destruction is to examine the univariate processes describing each series. In Table 5 we present $\mathrm{AR}(3)$ regressions using LRD data for net employment changes and rates of job creation and destruction. To capture within area (over time) dynamics we include state fixed effects (columns 1) while across region dynamics are captured by including time or year fixed effects (columns 2). ${ }^{7}$

The striking finding from table 5 is the general absence of persistence in net employment growth in manufacturing over this time period. The coefficients on lagged employment growth were less than 0.2 , with the coefficients on twice lagged growth being negative. The results from using BEA total economy-wide employment growth data show substantially more persistence both within and across regions than that found for manufacturing. The coefficient on lagged growth is 10 times bigger than found in manufacturing data. This result is consistent with the findings of Montgomery (1995), Eberts and Stone (1992), and Blanchard and Katz (1992) for longer sample periods.

Comparing the sum of the lagged coefficients suggests that there is far more persistence in net employment growth across states (column 2) than within a state (column 1). This is consistent with the findings of Blanchard and Katz (1992) of a high degree of persistence in relative employment growth rates. This conclusion is even more pronounced

7. Unfortunately, these data are available for only a limited time period so these AR results should only be viewed as suggestive of the true autoregressive structure of these series. Tests with the BEA manufacturing data, where longer time series are available, do, however, suggest that the estimated coefficients are not very sensitive to extending the sample period. 
when looking at the AR structure for the components of net employment growth in table 5 . For both job creation and destruction, the sum of the lagged coefficients in the across-state equations are four to ten times bigger (in absolute value) than in the within-state equations. These differences may indicate that different factors (or that the magnitude of the shocks to these factors) generate employment dynamics within versus across regions. These AR results also indicate that both within and across states, modest persistence in net employment dynamics hides somewhat greater persistence in employment creation and destruction.

Given some evidence for persistence in relative or across area employment growth rates, it is of interest to know whether relative employment levels move towards each other or towards some stationary equilibrium distribution of employment. That is, do the most rapidly growing areas have high or low initial levels of employment? If there is a unit root in relative employment, then shocks to regional employment will be permanent. Research by Barro and Sala-i-Martin (1991) and Carlino and Mills (1993) indicate that states or regions within the United States tend to exhibit $\beta$-convergence or conditional convergence in per capita income around a stationary steady state which is determined by initial conditions. ${ }^{8}$ Blanchard and Katz (1992) perform Dickey-Fuller tests for the presence of a unit root in employment and get mixed results, leading them to reject stationarity in employment. In contrast, Glaeser et al. using disaggregate city-industry data find much stronger evidence for mean reversion or convergence.

Given the concerns over the power of unit root tests (especially in a time series as

${ }^{8}$ Time series studies by Brown, Coulson, and Engle (1990) fail to find evidence for convergence across regions of the U.S. 
short as the one we have), we replicated the methodology of Barro and Sala-i-Martin (1992) to test for cross-sectional $\beta$-convergence in employment. The results from using BEA data for 1-digit industries relating employment growth over the interval 1973-88 to log of employment in 1973 are presented in table 6.

The BEA data suggest that total employment and nonfarm employment exhibit statistically significant $\beta$-convergence. The rate of convergence is, however, quite slow or about 10 percent of the rate of convergence in per capita income found in work by Barro and Sala-i-Martin. With the exception of agriculture and construction, employment growth in each of the 1-digit industries we examined also exhibits $\beta$-convergence. Again the estimated rates of convergence are quite low.

Recent work by Krugman (1991), Glaeser et al. (1992), and others have applied techniques from industrial organization to reanalyze some of the basic tenets of regional growth first developed by urban geographers and regional economists. The theoretical firm growth models of Jovanovic (1982) and others predict that, with barriers or fixed costs of entry, there will exist an inverse relationship between firm growth and firm size and age. ${ }^{9}$ Whether this will hold at an industry or labor market level of aggregation is open to question, but it does suggest the possibility that the size and age distribution of firms in an area might be correlated with area employment creation or growth.

Unfortunately, we do not have ready access to micro or establishment-level data at a regional level, which precludes us from estimating a disaggregate regional variant of these

${ }^{9}$ See Evans (1991) for a review of this literature and empirical tests of firm growth models. 
model. However, in table 7 we use the LRD data for manufacturing to estimate the relationship between net employment, job creation and job destruction and market size within and across areas. We find strong evidence for mean reversion within areas (cyclically) but only limited evidence for it across areas (secularly), as growth rates are negatively correlated with initial levels of population. Interestingly, within areas (columns 1-3) the negative correlation between initial size (population) and net employment growth comes about because of lower rates of job creation and considerably higher rates of destruction (columns 4-6). Across areas, however, the negligible effect of area size on net employment hides the fact that bigger areas have significantly lower rates of both job creation and destruction. Cross sectionally, bigger areas appear to have less dynamic labor markets with lower rates of creation and destruction largely offsetting each other. The size of the estimated coefficients both within and across areas points to potential differences in net employment dynamics in big versus small areas. In bigger states (or as a state grows) job creation appears to diminish more than job destruction suggesting that job destruction becomes an increasingly important determinant of net employment variations as areas grow.

Cabellero and Hammour (1994) extend the work of Jovanovic (1982) and others to consider how adjustment costs might affect the dynamic properties of industry creation and destruction. In their model, the higher these barriers to entry or the higher the adjustment costs, the more industries will smooth creation rates and accommodate demand fluctuations through variations in destruction rates. They find that a calibrated version of this model is 
consistent with industry variation in creation and destruction found in the data ${ }^{10}$ To the degree these adjustment costs vary over time, one might expect that the tendency to smooth fluctuations in job creation will diminish and that the sensitivity of creation to demand fluctuations will grow.

Empirically, Cabellero and Hammour (1994) regress Davis and Haltiwanger's job creation and job destruction components by industry against leads and lags of the respective index of industrial production. Using quarterly data, they find that the rate of job destruction is more responsive to changes in sectoral activity than is the rate of job creation. We replicate the estimation using Davis and Haltiwanger's annual time series data aggregated by state. Instead of the index of industrial production, we use annual percentage changes of BEA's gross state product data. Time and state dummy variables are entered to control for within-state (over time) variation and across-state variation. Table 8 displays the results.

Similar to Cabellero and Hammour's findings, we find that over time (when state dummy variables are included) the responsiveness of job destruction to annual changes in GSP is much larger than that of job creation for the contemporaneous and the contemporaneous and lagged specification combined. ${ }^{11}$ Across states, job creation is more responsive to GSP than is job destruction, regardless of whether the lead coefficient is or is not added to the sum of the contemporaneous and lagged coefficients. In addition to showing the relative response of job creation and job destruction to economic activity within and

${ }^{10}$ They also find that destruction rates are more sensitive to falling demand than to increasing industry demand.

11 The difference declines when the coefficient of the lead GSP variable is added to coefficients of the contemporaneous and lagged coefficients. 
across states, these tests are also suggestive of the importance of adjustment costs in explaining why the long-run dynamics may differ from these short-run patterns.

These "new" economic geography models also stress the potential importance of technological spillovers, agglomeration economies, and other location specific externalities in generating growth. Although the exact nature and role of these spillover effects is still a matter of debate, their presence is generally thought to be related to the knowledge or education base in the area. Work by Easterly and Rebelo (1993) and Easterly, Kremer. Pritchett, and Summers (1993), among others, suggest that government policy variables such as taxes and public infrastructure may also explain long-run growth differences. Finally, traditional regional studies like Terkla and Doeringer (1991) and others find that, at least in the short run, growth may be related to factor costs and unionization.

To test these predictions we use LRD data to estimate the impact on net employment growth and its components within and across areas of education (mean years of schooling), educational quality (average SAT scores), public infrastructure investment, and local taxes. We include measures of relative factor prices, unionization and year effects. These reduced form regressions are presented in table 9.

We find that higher input prices in an area seem to reduce the rate of job creation (column 1). High capital prices are negatively and significantly related to job creations, while the effect of high wages on job creation was found not to be statistically significant. The absence of a significant effect could mean that either regional wages are not far from their equilibrium levels or that they do not affect relative rates of job creation. Higher area wages increase the rate of job destruction, although again this effect is marginally significant. 
Contrary to our prior, we find that high energy and capital prices are associated with slower rates of job destruction in an area. This anomalous result may be due to the fact that input prices are correlated with other unobserved factors affecting job destruction.

In columns 2 we augment our simple specification to include other factors that previous research indicates may affect area growth. We add measures of unionization, the stock of public capital, taxes, and the quantity and quality of human capital in an area. The stock of public and human capital in an area have been the focus of much of the current endogenous growth literature as they are thought to generate either important private sector spillover effects or production externalities. Area unionization is negatively related to job growth and positively related to job contraction rates even controlling for area wages.

Whether this is causal cannot be determined based on these regressions. Unionism could be high in areas (industries) that experience the greatest adverse demand shocks because of technology or imports, or unions may adversely affect the business climate and hence firms' willingness to establish or expand employment in an area.

High levels of public capital appear to significantly increase the rate of job creation while high taxes reduce the rates of job creation. Somewhat perversely, areas with low taxes and public capital also appear to have higher rates of job destruction. Consistent with the findings in the endogenous growth literature, areas with higher average levels of schooling do appear to be able to have higher rates of job creation and lower rates of job destruction.

\section{Conclusion}

This paper offers an analysis of cyclical and secular patterns in job turnover using establishment-level data. We provide evidence that the job turnover process is markedly 
different over time and across regions. Over time, we find that employment fluctuations are associated primarily with job destruction. Across regions, employment differences are associated more with job creation. These findings do not appear to be the result of differences in data sets, since the same data sets yield the two different patterns of job turnover. The results are consistent with the endogenous growth literature, which focuses on long-run factors such as human capital externalities and technological spillovers to explain long-run differences in regional or national growth rates. Since the secular or across-state pattern differs from the cyclical pattern of net employment dynamics, caution should be used in extrapolating models of cyclical labor market dynamics to explain long-run or regional dynamics. It will be the challenge of future research to uncover the specific factors that contribute to these differences. 


\section{References}

Armington, Catherine and Marjorie Odle, "Small Business--How Many Jobs?" The Brookings Review, Winter 1982, pp.14-17.

Barro, Robert and Xavier Sala-i-Martin. "Convergence Across States and Regions", Brookings Papers on Economic Activity, vol. 1, 1991, 107-182.

Birch, David "Who Creates Jobs?", Public Interest, 65, Fall 1981, p. 3-14.

Brown, S., Coulson, N., and R. Engle, "Non-cointegration and Econometric Evaluation of Models of Regional Shift and Share", NBER working paper 3291, 1990.

Carlino, Gerald, and Leonard Mills, "Are U.S. Regional Incomes Converging?", Journal of Monetary Economics, vol. 32, no. 2, Nov. 1993, 335-346.

Cabellero, Ricardo J. and Mohamad L. Hammour, "The Cleansing Effect of Recessions," The American Economic Review, vol. 84, no. 5, Dec. 1994, 1350-1368.

Davis, Stephen and John Haltiwanger, " Gross Job Creation and Destruction: Microeconomic Evidence and Macroeconomic Implications," NBER Macroeconomics Annual, 5, 1990, p. 123- 168.

Dunne, Timothy, Mark Roberts, "Measuring Firm Entry. Growth, and Exit with Census of Manufacturers Data," Unpublished manuscript. University Park: Pennsylvania State University, Department of Economics, 1986.

Dunne, Timothy, Mark Roberts, and Larry Samuelson, "Plant Turnover and Gross Employment Flows in the U.S. Manufacturing Sector," Journal of Labor Economics vol. 7 , no. 1,1989 , pp. 48-71.

Easterly, W., Kremer, M., Pritchett, L. and L. Summers," Good Policy or Good Luck? Country Growth Performance and Temporary Shocks", Journal of Monetary Economics, vol. 32, no. 3, December 1993, 459-484.

Easterly, W., and S. Rebelo," Fiscal Policy and Economic Growth: An Empirical Investigation", Journal of Monetary Economics, vol. 32. no. 3, December 1993, 417-458.

Eberts, Randall and Joe Stone, Wage and Employment Adjustment in Local Labor Markets, W.E. Upjohn Institute, Kalamazoo, MI, 1992. 
Eberts, Randall and Edward Montgomery, "Employment Creation and Destruction: An Analytical Review", Economic Review, Federal Reserve Bank of Cleveland, vol. 30. no.3, 1994.

Evans, David, "Tests of Alternate Theories of Firm Growth", Journal of Political Economy, vol.95, no. 4, August 1987, 657-674.

Glaeser, Edward, Heidi Kallal, Jose Scheinkman, and Andrei Shleifer, "Growth of Cities", Journal of Political Economy, vol. 100, no. 6, December 1992, 1126-1152.

Howland, Marie, Plant Closings and Worker Displacement: The Regional Issues, W.E. Upjohn Institute for Employment Research, 1988.

Jacobson, Louis, "Analysis of the Accuracy of SBA's Small Business Data Base," Working Paper 85-1958, Center for Naval Analyses, Alexandria ,VA, October 23, 1985.

Jacobson, Louis, "Job Creation and Destruction in Pennsylvania, 1975-85," unpublished manuscript. Kalamazoo, MI: W. E. Upjohn Institute for Employment Research, 1986.

Jovanovic, Boyan, "Selection and the Evolution of Industry", Econometrica, vol.50, no.3, May 1982, 649-670.

Kremer, Micheal, "Population Growth and Technological Change: One Million B.C. to 1990", Quarterly Journal of Economics, vol. 108, no.3, August 1993, 681-716.

Krugman, Paul, "Increasing Returns and Economic Geography", Journal of Political Economy, vol.99, June 1991, 483-99.

Leonard, Jonathan, "In the Wrong Place at the Wrong Time: The Extent of Frictional and Structural Unemployment", in Unemployment \& the Structure of Labor Markets, edited by Kevin Lang and Jonathan Leonard, Basil Blackwell: New York, 1987.

Lucas, Robert, "On the Mechanics of Economic Development", Journal of Monetary Economics, vol.22, July $1988,3-42$.

Montgomery, Edward, "Patterns in Regional Labor Market Adjustment: The United States versus Japan" in Social Protection versus Economic Flexibility, R. Blank ed., University of Chicago Press, Chicago, IL, 1995.

Romer, Paul, "Increasing Returns and Long Run Growth", Journal of Political Economy, vol. 94, October 1986, 1002-1037. 
Terkla, David and Peter Doeringer, "Explaining Variations in Employment Growth:

Structural and Cyclical Changes Among States and Local Areas", Journal of Urban Economics, vol. 29, no.3, May 1991, 329-348. 
Figure 1: Job Creation and Destruction over Time

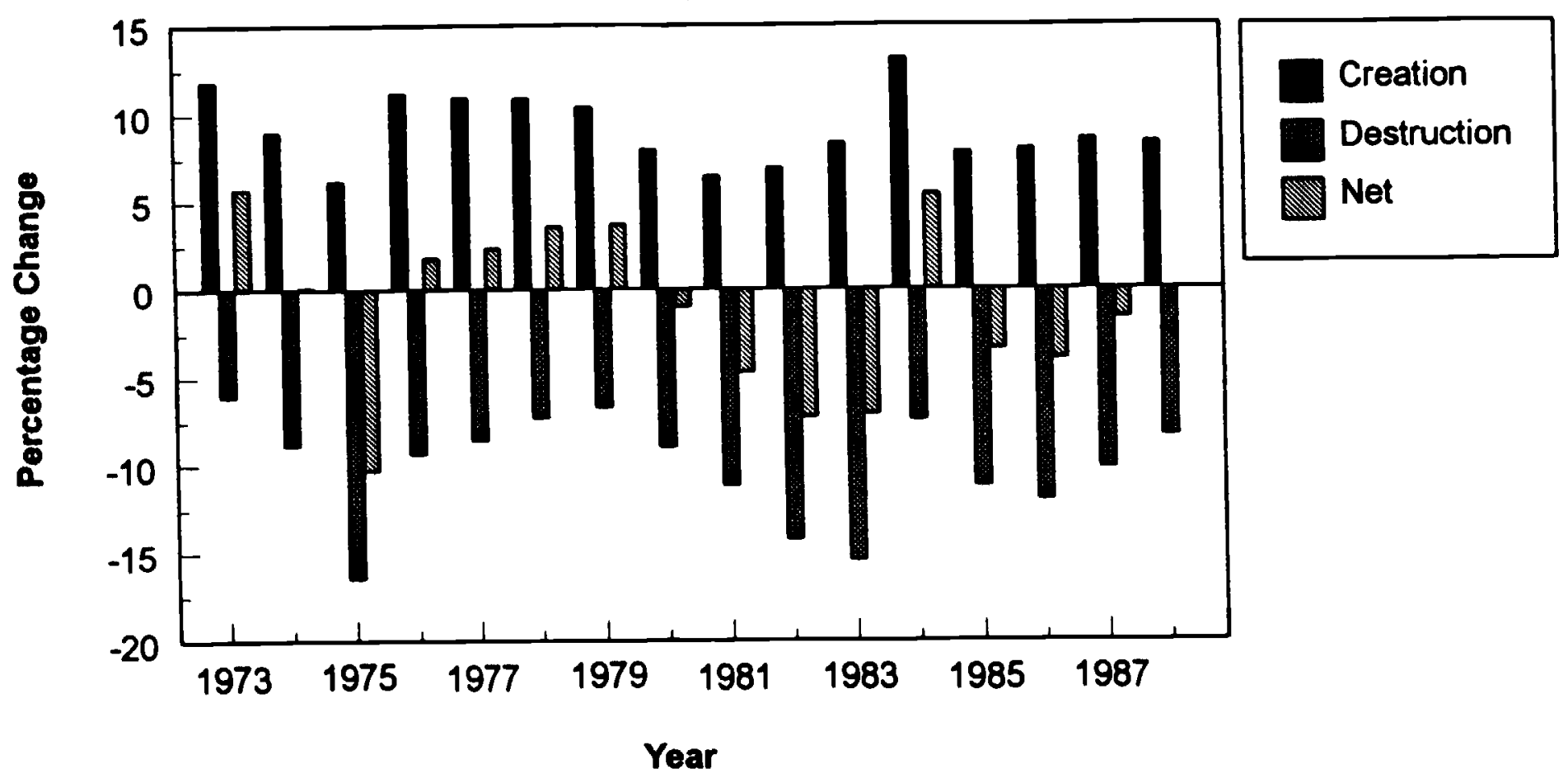

Source: Davis and Haltiwanger LRD regional data, averaged across regions. 
Figure 2: Components of Job Creation and Destruction

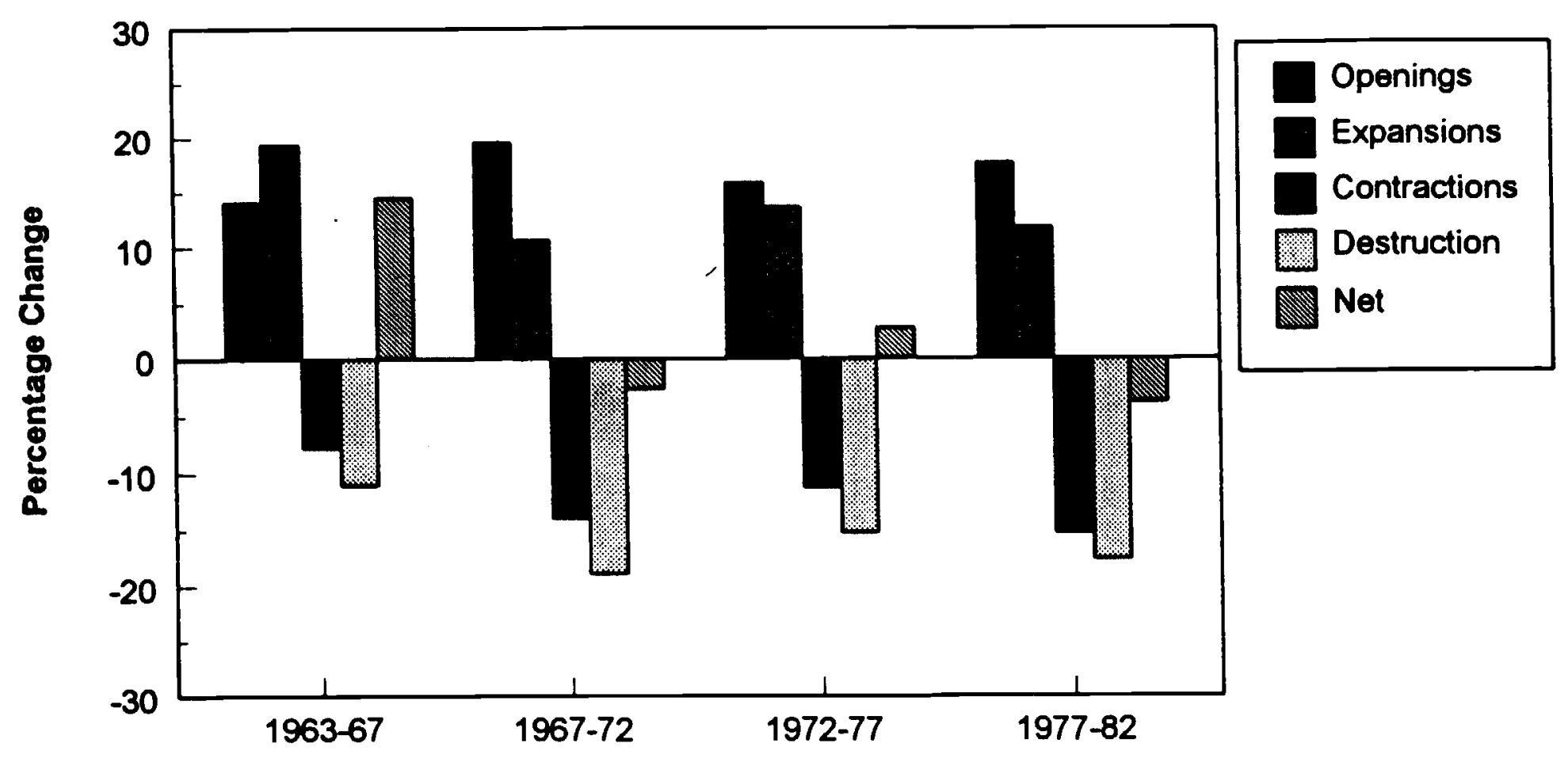

Source: Dunne, Roberts, and Samuelson (1989) 
Figure 3: Job Creation and Destruction Across Regions

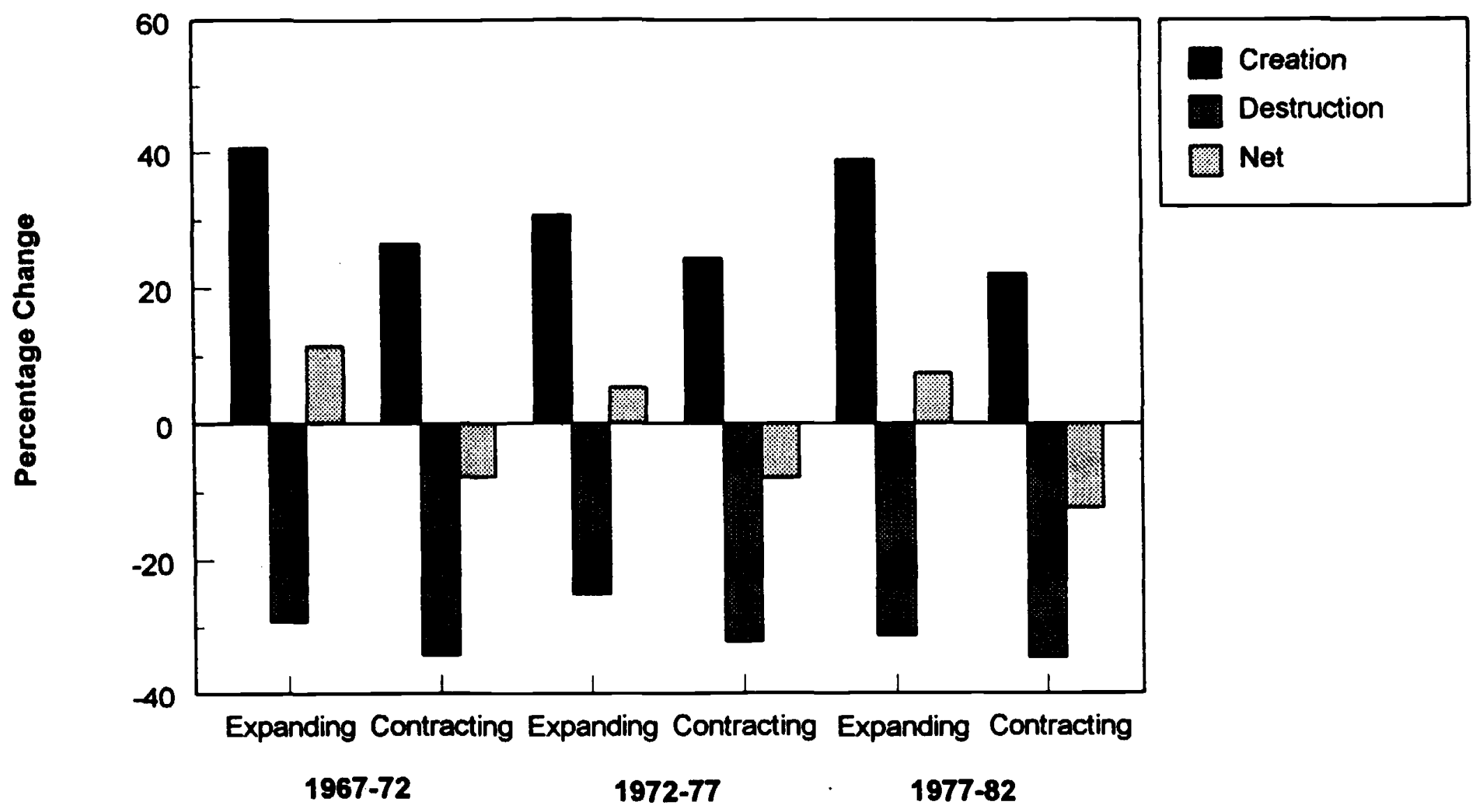

Source: Dunne, Roberts, and Samuelson (1989) 
Figure 4: Employment Components:

Expanding Regions

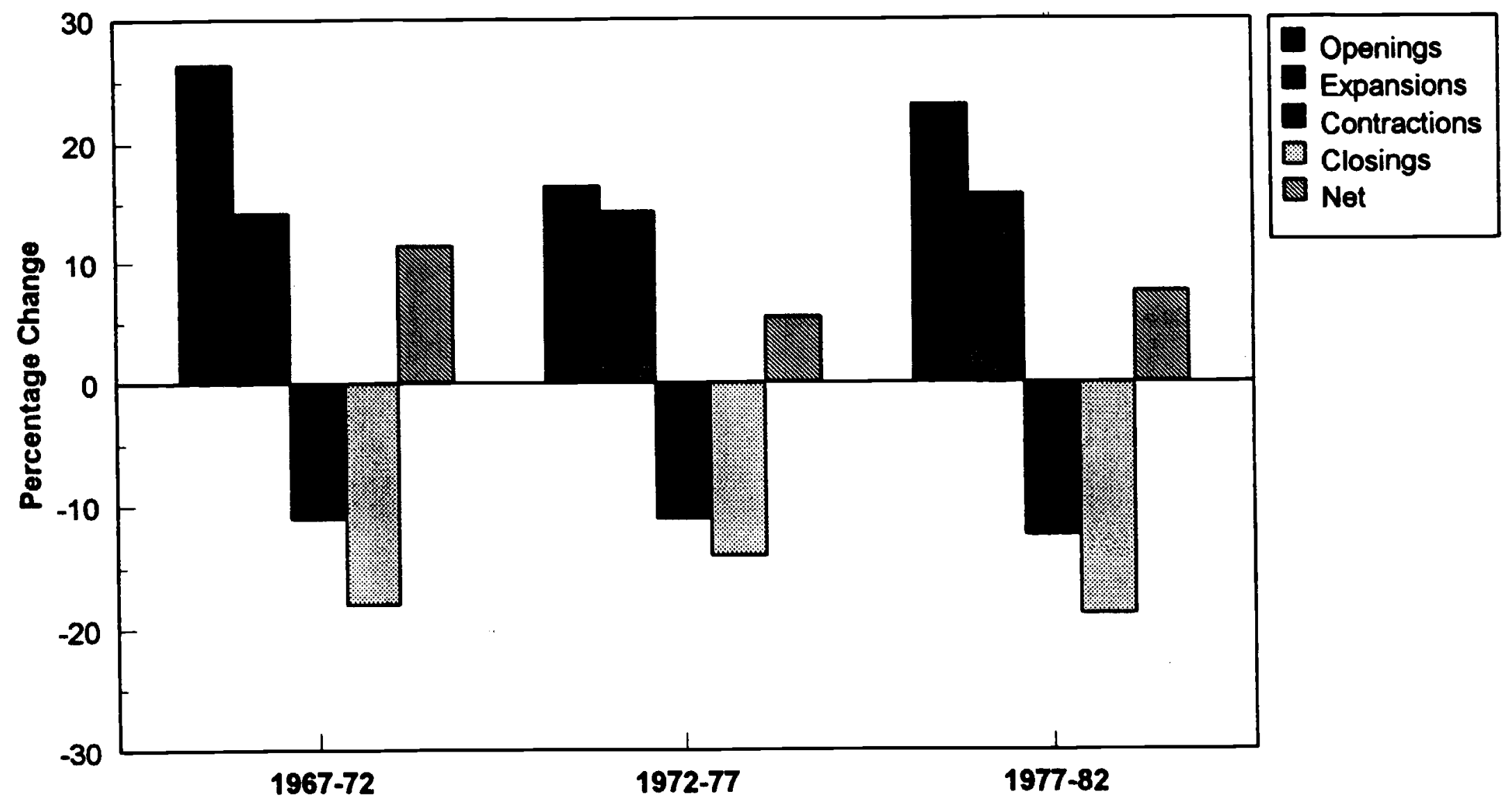

Source: Dunne, Roberts, and Samuelson (1989) 
Figure 5: Employment Components:

Contracting Regions

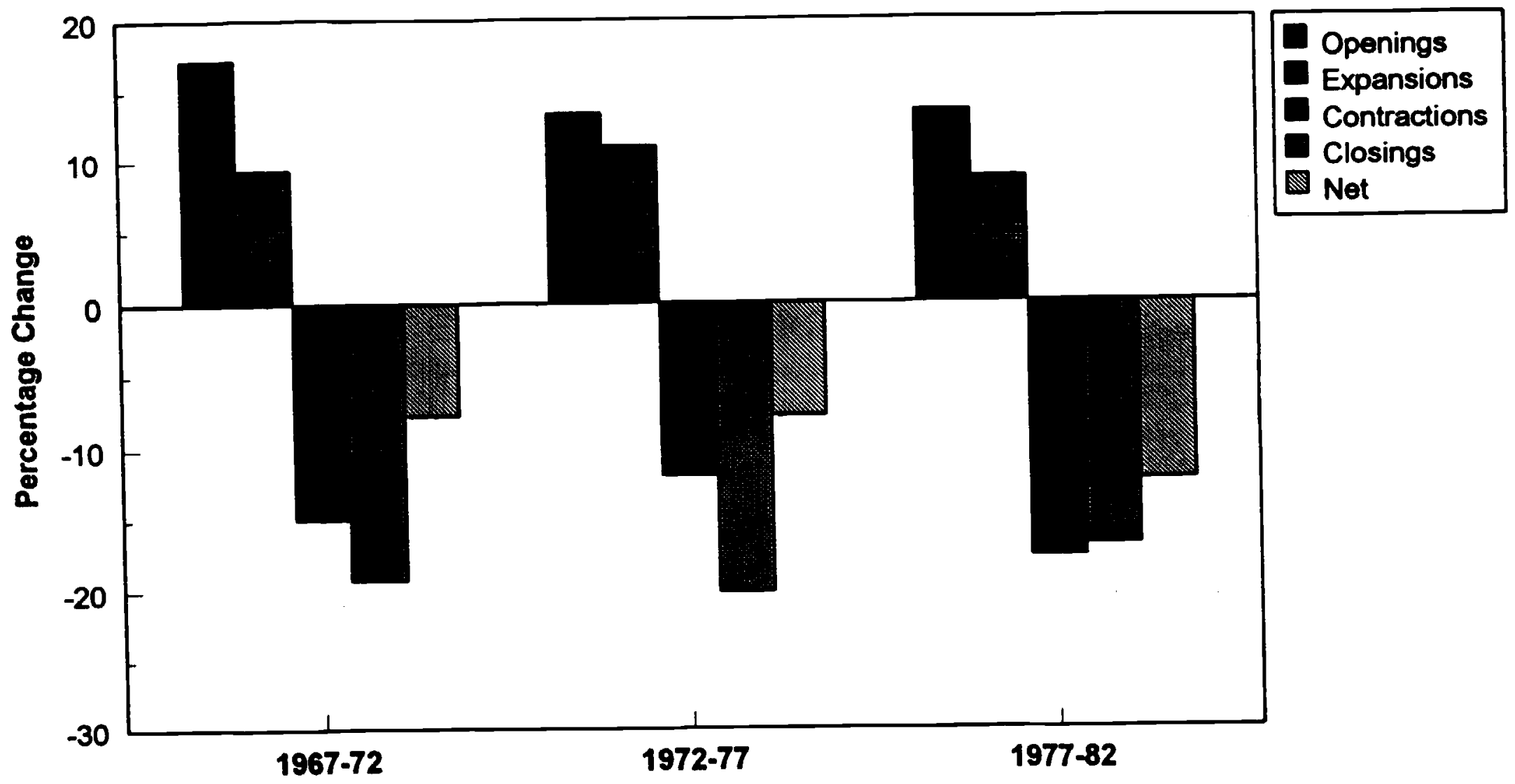

Source: Dunne, Roberts, and Samuelson (1989) 
Figure 6: Decomposition of Sum of Squares for Job Creation and Destruction

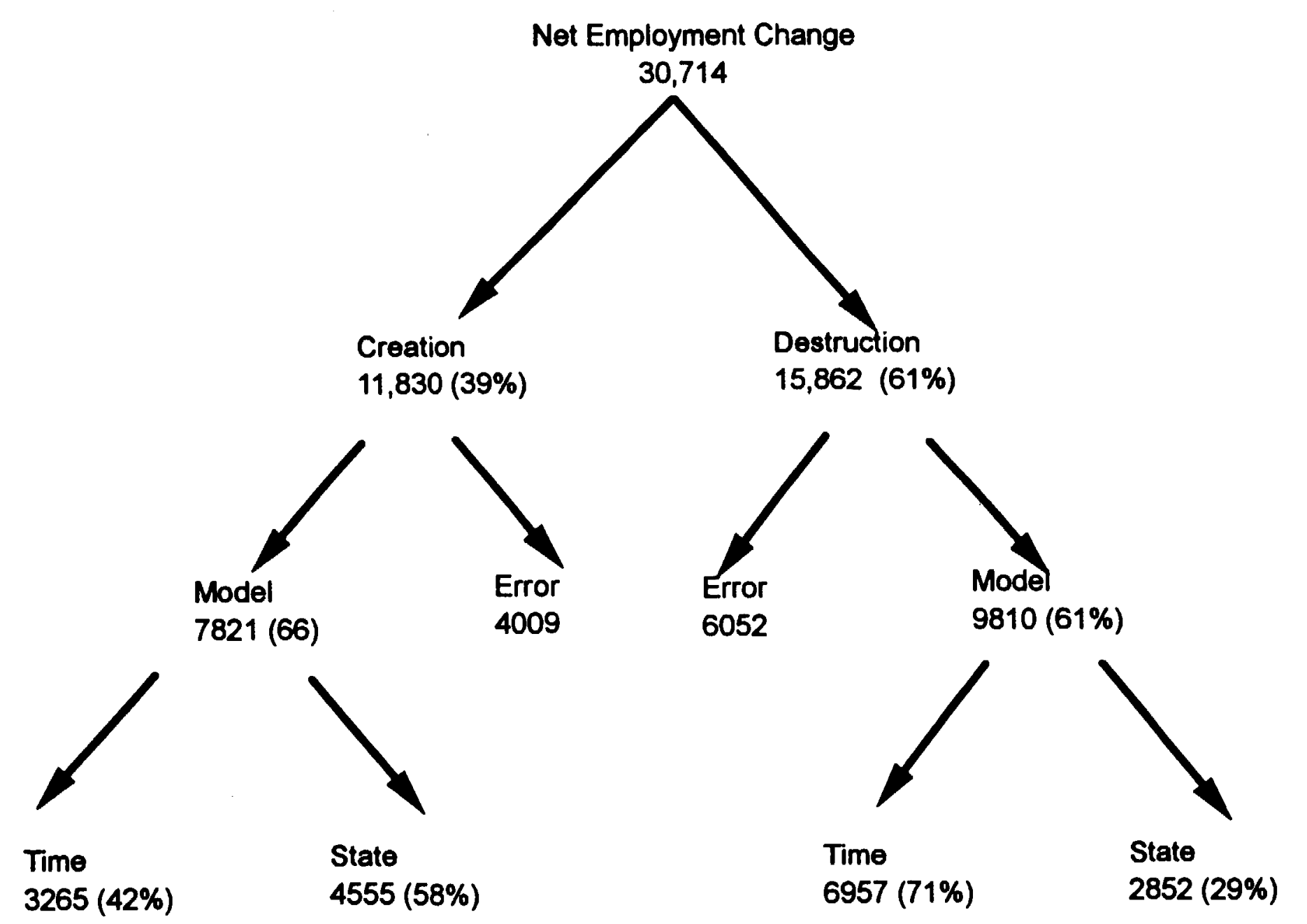

Source: Authors' calculations. 
Table 1

Summary of Employment Components

\begin{tabular}{|c|c|c|c|c|c|c|c|c|c|c|c|}
\hline \multirow[b]{2}{*}{ Study } & \multirow[b]{2}{*}{$\begin{array}{l}\text { Time } \\
\text { Period }\end{array}$} & \multirow[b]{2}{*}{ Interval } & \multirow[b]{2}{*}{ Region } & \multirow[b]{2}{*}{ Industry } & \multicolumn{5}{|c|}{ Annual Employment Change } & \multirow[b]{2}{*}{$\begin{array}{l}\text { Openings/ } \\
\text { Creation }\end{array}$} & \multirow[b]{2}{*}{$\begin{array}{l}\text { Closings/ } \\
\text { Destructior }\end{array}$} \\
\hline & & & & & Openings & Expansion & Contraction & Closings & $\mathrm{Net}$ & & \\
\hline \multicolumn{12}{|l|}{ UI Data: } \\
\hline Leonard (1987) & 1977-82 & 1 year & W1 & All & $2.5 \%$ & $11.3 \%$ & $-8.8 \%$ & $-2.2 \%$ & $2.8 \%$ & $18 \%$ & $12 \%$ \\
\hline Jacobson (1986) & 1979-85 & 6 years & $\mathrm{PA}$ & All & 5.3 & 2.2 & -2.3 & -5.0 & 0.1 & 71 & 68 \\
\hline \multicolumn{12}{|l|}{ Dun \& Bradstreet } \\
\hline Armington \& Odle (1982) & $1976-82$ & 6 years & US & All & 4.8 & 3.7 & -2.2 & -3.7 & 2.6 & 56 & 63 \\
\hline Armington \& Odle (1982) & $1976-82$ & 6 years & US & Mfg. & 3.9 & 3.1 & -2.1 & -4.0 & 0.9 & 56 & 66 \\
\hline $\begin{array}{l}\text { Eberts \& Montgomery } \\
\text { (current) }\end{array}$ & $1976-78$ & 2 years & us & All & 6.5 & 7.1 & -4.6 & -5.0 & 4.0 & 48 & 52 \\
\hline $\begin{array}{l}\text { Eberts \& Montgomery } \\
\text { (Current) }\end{array}$ & $1980-82$ & 2 years & US & All & 4.3 & 5.6 & -4.0 & -5.3 & 0.6 & 43 & 57 \\
\hline \multicolumn{12}{|l|}{ Census Bureau: } \\
\hline Dunne, et al. (1989) & $1977-82$ & 5 years & US & Mfg. & 3.5 & 2.3 & -3.1 & -3.5 & -0.8 & 60 & 53 \\
\hline Davis \& Haltiwanger (1990) & $1979-83$ & 1 year & US & Mfg. & 1.6 & 6.4 & -9.7 & -3.0 & -5.0 & 20 & 24 \\
\hline SBA & $1989-90$ & 1 year & US & Total & 3.2 & 13.5 & -9.8 & -4.9 & 2.0 & 19 & 33 \\
\hline SBA & $1990-91$ & 1 year & US & Total & 3.3 & 11.6 & -11.7 & -4.8 & -1.2 & 22 & 29 \\
\hline SBA & $1989-90$ & 1 year & US & MAN & 2.1 & 8.1 & -8.6 & -3.4 & -1.9 & 20 & 29 \\
\hline SBA & $1990-91$ & 1 year & US & MAN & 2.0 & 7.1 & -10.1 & -3.2 & -4.4 & 22 & 24 \\
\hline
\end{tabular}

Source: See References

Note: Changes are calculated as a percentage of beginning-period employment. 
Table 2

Employment Changes by SMSA (percent)

\begin{tabular}{|c|c|c|c|c|c|c|c|c|c|}
\hline & \multicolumn{3}{|c|}{ Overall } & \multicolumn{3}{|c|}{ Expanding SMSAs } & \multicolumn{3}{|c|}{ Contracting SMSAs } \\
\hline & $1976-78$ & $1980-82$ & $1984-86$ & 1976-78 & $1980-82$ & $1984-86$ & $1976-78$ & $1980-82$ & $1984-86$ \\
\hline Net Change & 8.0 & 1.6 & 5.9 & 9.6 & 4.6 & 7.4 & -3.5 & -3.3 & -6.4 \\
\hline Openings & 13.0 & 8.7 & 17.2 & 13.5 & 9.8 & 17.7 & 9.2 & 6.9 & 13.0 \\
\hline Closings & -9.9 & -10.5 & -14.6 & -9.7 & -10.6 & -14.2 & -11.8 & -10.5 & -17.4 \\
\hline Expansions & 14.2 & 11.3 & 9.3 & 14.8 & 12.7 & 9.6 & 10.3 & 9.0 & 6.5 \\
\hline Contractions & -9.3 & -7.9 & -6.0 & -9.0 & -7.4 & -5.7 & -11.2 & -8.8 & -8.6 \\
\hline Creation & 27.2 & 20.1 & 26.5 & 28.3 & 22.6 & 27.3 & 19.5 & 16.0 & 19.5 \\
\hline Destruction & -19.3 & -18.4 & -20.6 & -18.7 & -17.9 & -19.9 & -25.0 & -19.3 & -26.0 \\
\hline Gross Change & 46.5 & 38.5 & 47.0 & 47.0 & 40.5 & 47.2 & 42.6 & 35.2 & 45.5 \\
\hline Number of SMSA & 263 & 263 & 263 & 239 & 141 & 209 & 24 & 122 & 54 \\
\hline
\end{tabular}

Notes: The changes are calculated as a percentage of beginning-period employment.

Creation is defined as openings plus expansions. Destruction is defined as closings plus contractions.

Source: Authors calculations based on Small Business Administration USEEM data. 
Table 3: Correlation of Employment Components with Net Employment Change within States, LRD Manufacturing data, 1973-1988

\begin{tabular}{|l|l|l|l|}
\hline & \multicolumn{2}{|l|}{ Correlation } & \multicolumn{2}{l|}{$\begin{array}{l}\text { Creation with } \\
\text { Destruction }\end{array}$} \\
\hline & Net Employment Change with & -0.58 \\
\hline & Creation & Destruction & \\
\hline $\begin{array}{l}\text { Average across all } \\
\text { states }\end{array}$ & 0.85 & -0.91 & \\
\hline & & & \\
\hline Range of Correlation & Number of States: & & \\
\hline $0.50-0.59$ & 1 & 0 & \\
\hline $0.60-0.69$ & 2 & 2 & \\
\hline $0.70-0.79$ & 6 & 2 & \\
\hline $0.80-0.89$ & 25 & 6 & \\
\hline $0.90-0.99$ & 16 & 40 & \\
\hline
\end{tabular}

Note: Data are from Davis and Haltiwanger's LRD manufacturing data set. 
Table 4: Correlation of Employment Components with Net Employment Change across States, Manufacturing

\begin{tabular}{|c|c|c|c|}
\hline \multirow[b]{3}{*}{ Year } & \multicolumn{3}{|l|}{ Correlation } \\
\hline & \multicolumn{2}{|c|}{ Net Employment Change with: } & \multirow{2}{*}{$\begin{array}{l}\text { Creation with } \\
\text { Destruction }\end{array}$} \\
\hline & Creation & Destruction & \\
\hline 1973 & 0.85 & -0.14 & 0.40 \\
\hline 1974 & 0.46 & -0.54 & 0.49 \\
\hline 1975 & 0.79 & -0.73 & -0.16 \\
\hline 1976 & 0.85 & -0.61 & -0.10 \\
\hline 1977 & 0.52 & -0.57 & 0.42 \\
\hline 1978 & 0.71 & -0.49 & 0.26 \\
\hline 1979 & 0.76 & -0.30 & 0.39 \\
\hline 1980 & 0.78 & -0.63 & -0.01 \\
\hline 1981 & 0.79 & -0.79 & -0.25 \\
\hline 1982 & 0.21 & -0.84 & 0.34 \\
\hline 1983 & 0.01 & -0.83 & 0.56 \\
\hline 1984 & 0.69 & -0.65 & 0.10 \\
\hline 1985 & 0.58 & -0.55 & 0.36 \\
\hline 1986 & 0.72 & -0.64 & 0.08 \\
\hline 1987 & 0.73 & -0.77 & -0.11 \\
\hline 1988 & 0.73 & -0.54 & 0.09 \\
\hline $\begin{array}{l}\text { Average } \\
1973-1988 \\
\end{array}$ & 0.64 & -0.60 & 0.18 \\
\hline 1990 & 0.77 & -0.39 & 0.28 \\
\hline 1991 & 0.67 & -0.41 & 0.41 \\
\hline
\end{tabular}

Note: Data for 1973-1988 are from Davis and Haltiwanger's LRD manufacturing data set; data for 1990-91 come from Census-based SBA data for manufacturing. 
Table 5

Univariate Models of Net Employment and Job Creation and Destruction

\begin{tabular}{|c|c|c|c|c|c|c|c|c|}
\hline \multirow[b]{2}{*}{ Dependent Variable } & \multicolumn{6}{|c|}{ Manufacturing (LRD) } & \multirow{2}{*}{\multicolumn{2}{|c|}{$\frac{\text { Total (BEA) }}{\text { Net }}$}} \\
\hline & & (2) & ${ }_{(1)}^{\mathrm{Cr}}$ & ion & $\begin{array}{l}\text { Des } \\
\text { (1) }\end{array}$ & $\begin{array}{l}\text { ction } \\
\text { (2) }\end{array}$ & & (2) \\
\hline LAG 1 & $\begin{array}{c}0.06 \\
(1.58)\end{array}$ & $\begin{array}{c}0.04 \\
(0.99)\end{array}$ & $\begin{array}{c}0.13 \\
(3.14)\end{array}$ & $\begin{array}{c}0.27 \\
(6.90)\end{array}$ & $\begin{array}{c}0.14 \\
(3.54)\end{array}$ & $\begin{array}{c}0.24 \\
(6.28)\end{array}$ & $\begin{array}{c}0.57 \\
(16.0)\end{array}$ & $\begin{array}{c}0.80 \\
(22.9)\end{array}$ \\
\hline LAG 2 & $\begin{array}{c}-0.11 \\
(-2.73)\end{array}$ & $\begin{array}{l}-0.01 \\
(.26)\end{array}$ & $\begin{array}{l}-0.07 \\
(1.78)\end{array}$ & $\begin{array}{l}0.15 \\
(3.75)\end{array}$ & $\begin{array}{c}-0.13 \\
(3.47)\end{array}$ & $\begin{array}{c}0.06 \\
(1.54)\end{array}$ & $\begin{array}{l}-0.35 \\
(-8.89)\end{array}$ & $\begin{array}{l}-0.29 \\
(6.48)\end{array}$ \\
\hline LAG 3 & $\begin{array}{l}-0.11 \\
(-2.96)\end{array}$ & $\begin{array}{l}0.03 \\
(.99)\end{array}$ & $\begin{array}{l}-0.11 \\
(2.82)\end{array}$ & $\begin{array}{c}0.16 \\
(4.11)\end{array}$ & $\begin{array}{l}-0.12 \\
(3.00)\end{array}$ & $\begin{array}{c}0.14 \\
(3.65)\end{array}$ & $\begin{array}{l}-0.04 \\
(-1.74)\end{array}$ & $\begin{array}{c}0.14 \\
(3.85)\end{array}$ \\
\hline Sum of lags & -0.15 & 0.06 & -0.05 & 0.58 & -0.11 & 0.44 & 0.18 & 0.65 \\
\hline State fixed effects & Yes & No & Yes & No & Yes & No & Yes & No \\
\hline Time dummies & No & Yes & No & Yes & No & Yes & No & Yes \\
\hline
\end{tabular}

Notes: t-statistics in parentheses.

Source: Davis and Haltiwanger's LRD manufacturing data, and BEA data for total employment. 
Table 6: Estimates of Convergence of Net Employment Change, 1973-1988

\begin{tabular}{|l|l|r|r|}
\hline Industry & $\begin{array}{l}\text { Coefficient on Log } \\
\text { 1973 Employment }\end{array}$ & $\begin{array}{l}\boldsymbol{\beta} \text {-Convergence } \\
\text { Coefficient }\end{array}$ & R-Square \\
\hline Total Employment & $-.00221(-1.65)$ & 0.0022 & 0.05 \\
\hline Private, Nonfarm & $-.00346(-2.56)$ & 0.0034 & 0.12 \\
\hline Agriculture & $.00069(.27)$ & -0.0007 & 0.002 \\
\hline Mining & $-.0043(-1.83)$ & 0.0042 & 0.06 \\
\hline Construction & $.00156(.69)$ & -0.0016 & 0.01 \\
\hline Manufacturing & $-.00578(-4.56)$ & 0.0055 & 0.30 \\
\hline Transportation and Utilities & $-.00325(-2.29)$ & 0.0032 & 0.10 \\
\hline Wholesale Trade & $-.00329(-2.00)$ & 0.0032 & 0.08 \\
\hline Retail Trade & $-.00201(-1.31)$ & 0.0020 & 0.03 \\
\hline FIRE & $-.00327(-2.37)$ & 0.0032 & 0.10 \\
\hline Services & $-.00130(-.95)$ & 0.0013 & 0.02 \\
\hline
\end{tabular}

Note: Regressed annual growth rate of employment between 1973 and 1988 on log of 1973 employment.

Source: BEA employment data. 
Table 7: Relationship between Employment Components and Market Size

\begin{tabular}{|l|l|l|l|l|l|l|}
\hline Variables & Net & Creation & Destruction & Net & Creation & Destruction \\
\hline & 1 & 2 & 3 & 4 & 5 & 6 \\
\hline $\begin{array}{l}\text { State } \\
\text { Population }\end{array}$ & -50.66 & -17.68 & 32.97 & -0.16 & -0.48 & -0.32 \\
\hline (t-statistics) & $(-5.52)$ & $(-4.10)$ & $(5.34)$ & $(-0.80)$ & $(-3.83)$ & $(-2.04)$ \\
\hline $\begin{array}{l}\text { Dummy } \\
\text { Variables }\end{array}$ & State & State & State & Time & Time & Time \\
\hline R-Squared & 0.13 & 0.31 & 0.21 & 0.58 & 0.41 & 0.49 \\
\hline
\end{tabular}

Note: Explanatory variables are in natural logs.

Source: Davis and Haltiwanger's LRD manufacturing data and Census of Population. 
Table 8: Job Creation and Job Destruction Response to Output Growth, 1973-1988

\begin{tabular}{|c|c|c|c|c|c|c|c|c|c|}
\hline & \multicolumn{3}{|c|}{ Job Creation } & \multicolumn{3}{c|}{ Job Destruction } & \multicolumn{3}{c|}{ Net Change } \\
\hline Dummy Variables & None & Time & State & None & Time & State & None & Time & State \\
\hline & & & & & & & & \\
\hline GSP (t+1) & 0.102 & 0.232 & 0.112 & 0.171 & 0.017 & 0.155 & 0.021 & 0.215 & -0.043 \\
\hline t-statistics & 5.96 & 7.18 & 3.95 & 4.50 & 0.49 & 4.11 & 0.40 & 5.11 & -0.75 \\
\hline & & & & & & & & & \\
\hline GSP (0) & 0.326 & 0.190 & 0.270 & -0.276 & -0.056 & -0.338 & 0.600 & 0.247 & 0.610 \\
\hline t-statistics & 11.07 & 5.98 & 10.78 & -7.83 & -1.70 & -9.96 & 13.03 & 6.08 & 12.30 \\
\hline & & & & & & & & \\
\hline GSP (t-1) & 0.195 & 0.142 & 0.119 & -0.233 & 0.005 & -0.288 & 0.428 & 0.136 & 0.407 \\
\hline t-statistics & 6.35 & 4.39 & 4.50 & -6.57 & 0.16 & -8.42 & 8.85 & 3.29 & 7.87 \\
\hline & & & & & & & & & \\
\hline Sum 0,t-1 & 0.521 & 0.332 & 0.389 & -0.509 & -0.051 & -0.626 & 1.028 & 0.383 & 1.107 \\
\hline t+1,0,t-1 & 0.623 & 0.564 & 0.501 & -0.338 & -0.034 & -0.471 & 1.049 & 0.598 & 0.974 \\
\hline
\end{tabular}

Source: Davis and Haltiwanger LRD data set for manufacturing, and BEA Gross State Product 
Table 9: Determinants of Regional Job Creation and Destruction Rates

\begin{tabular}{|c|c|c|c|c|c|c|}
\hline \multirow[t]{2}{*}{ Variables } & \multicolumn{2}{|c|}{$\mathrm{Net}$} & \multicolumn{2}{|c|}{ Creation } & \multicolumn{2}{|c|}{ Destruction } \\
\hline & 1 & 2 & 1 & 2 & 1 & 2 \\
\hline Wage Rates & $\begin{array}{c}-2.51 \\
(-1.46)\end{array}$ & $\begin{array}{c}-5.33 \\
(-1.89)\end{array}$ & $\begin{array}{c}-0.23 \\
(-0.21)\end{array}$ & $\begin{array}{l}-3.11 \\
(-1.81)\end{array}$ & $\begin{array}{c}2.27 \\
(1.69)\end{array}$ & $\begin{array}{c}2.22 \\
(1.02)\end{array}$ \\
\hline $\begin{array}{l}\text { Rental Price of } \\
\text { Capital }\end{array}$ & $\begin{array}{c}-0.12 \\
(-0.41)\end{array}$ & $\begin{array}{c}0.47 \\
(1.46)\end{array}$ & $\begin{array}{c}-0.38 \\
(-2.14)\end{array}$ & $\begin{array}{c}0.36 \\
(1.81)\end{array}$ & $\begin{array}{c}-0.27 \\
(-1.22)\end{array}$ & $\begin{array}{c}-0.12 \\
(-0.47)\end{array}$ \\
\hline Energy Price & $\begin{array}{c}0.60 \\
(0.84)\end{array}$ & $\begin{array}{c}0.05 \\
(0.06) \\
\end{array}$ & $\begin{array}{c}-0.74 \\
(-1.64)\end{array}$ & $\begin{array}{c}0.29 \\
(0.58) \\
\end{array}$ & $\begin{array}{l}-1.34 \\
(-2.42)\end{array}$ & $\begin{array}{c}0.24 \\
(0.38) \\
\end{array}$ \\
\hline Unionization & & $\begin{array}{c}-0.13 \\
(-3.10)\end{array}$ & & $\begin{array}{c}-0.06 \\
(-2.26)\end{array}$ & & $\begin{array}{c}0.07 \\
(2.21)\end{array}$ \\
\hline $\begin{array}{l}\text { Public Capital } \\
\text { Stock/Capita }\end{array}$ & & $\begin{array}{c}-0.23 \\
(-0.19)\end{array}$ & & $\begin{array}{c}3.22 \\
(4.49)\end{array}$ & & $\begin{array}{c}3.45 \\
(3.75)\end{array}$ \\
\hline $\begin{array}{l}\text { Tax Revenue/ } \\
\text { GSP }\end{array}$ & & $\begin{array}{c}1.48 \\
(0.85)\end{array}$ & & $\begin{array}{c}-2.29 \\
(-2.14)\end{array}$ & & $\begin{array}{l}-3.77 \\
(-2.76)\end{array}$ \\
\hline $\begin{array}{l}\text { Years of } \\
\text { Education }\end{array}$ & & $\begin{array}{l}34.33 \\
(3.13)\end{array}$ & & $\begin{array}{l}23.14 \\
(3.47)\end{array}$ & & $\begin{array}{l}-11.19 \\
(-1.31)\end{array}$ \\
\hline SAT scores & & $\begin{array}{c}-3.60 \\
(-1.02)\end{array}$ & & $\begin{array}{l}-1.55 \\
(-0.72)\end{array}$ & & $\begin{array}{c}2.04 \\
(0.74)\end{array}$ \\
\hline R-Squared & 0.57 & 0.60 & 0.39 & 0.47 & 0.48 & 0.50 \\
\hline
\end{tabular}

Note: All explanatory variables in natural logs and lagged one period, except union membership. Time dummy variables are entered in all equations. 